\title{
THE ACTION OF XeCl*-LASER RADIATION ON TEMPERATURE DEPENDENCE OF POROUS SILICON LUMINESCENCE INTEGRAL INTENSITY
}

\author{
S. M. Baschenko, I. V. Blonskyy, Yu. O. Skryshevskyy \\ Institute of Physics of the National Academy of Sciences of Ukraine \\ 46 Nauky Pr., Kyiv, UA-03039, Ukraine \\ (Received July 7, 1999; received in final form January 17, 2000)
}

\begin{abstract}
For the first time a possibility to influence on the shape of temperature dependence of integral intensity of luminescence $I_{\mathrm{lum}}(T)$ in the region of orange-red luminescence band for the por-Si samples by UV-irradiation has been demonstrated. In the type 1 samples two spectral components have been elucidated, each differently reacting on the UV-irradiation phase and on the temperature change. It is concluded that different shapes of the $I_{\text {lum }}(T)$ dependence previously observed on various samples by a varying groups of investigators is stipulated by different active contribution into the resulting shape of the short-wavelength (L) and long-wavelength (M) luminescence bands and, possibly, other emission bands. The nature of the UV irradiation influence on the $I_{\text {lum }}(T)$ dependencies is analysed.
\end{abstract}

Key words: porous silicon, photoluminescence, temperature dependence of luminescence, $\mathrm{XeCl}^{*}$-laser radiation.

PACS number(s): 71.55.-i, 78.55.Fv

\section{INTRODUCTION}

In works $[1,2]$ it was reported about one more anomaly of the porous silicon (por-Si) luminescent light, which is inherent to the orange-red emission band: nonmonotonic change of integral intensity of the luminescence as a function of temperature, $I_{\text {lum }}(T)$. A similar dependence is shown in Fig. 1, 2. Various models were also proposed to explain the cause of the integral intensity of luminescence increasing in the region of low temperatures $(4.5 \mathrm{~K}<T<120 \mathrm{~K})$ and its subsequent decreasing in a higher temperature region $(120 \mathrm{~K}<T<300 \mathrm{~K})$. All the models proposed were possessed of a common feature - the orange-red luminescence band had been explained by localized oscillators. That is why when explaining the cause of the non-monotonic feature of the $I_{\text {lum }}(T)$ dependence one has accounted for the peculiarities the temperature influence on the processes determining the efficiency of radiative $1 / \tau$ and non-radiative $1 / \tau_{N R}$ transitions in an ensemble of the localized por-Si oscillators. In particular, in [1] same attention is paid to the possibility of realisation of the "bottleneck" effect in por-Si for the non-radiative transitions genetically connected with the so called "change of localisation region" within the "tail" area of localized states: $\tau^{\sim} \exp (-2 \alpha R-\delta / k T)$ with $\alpha$ being the length of localisation, $R$ - distance between two spatially separated states, $\delta$ - the activation barrier height. In this case $\tau_{N R}$ will be determined by two factors: i) the measure of overlapping of the wave functions in initial and final states of the charge carriers and ii) the height of activation barrier. Such a dependence of the non-radiative transitions on the two factors, in its turn, often leads to anomalies of the transportation properties of charge carriers at low temperatures in the disordered materials [3] and promotes manifestation of the non-monotonic feature in the $I_{\text {lum }}(T)$ dependence as well $[1,2,4]$.

The non-monotonic feature is also inherent to the $I_{\text {lum }}$ vs $D$ ( $\gamma$-radiation doze) dependence [5]. The most likely explanation of the $I_{\text {lum }}(D)$ dependence is associated by the authors of [5] with a mechanism of $\gamma$-irradiation influence on por-Si according to which at the first stage (low dozes, $D<10^{19} \mathrm{~cm}^{-2}$ ) a formation of effective centres of the charge carriers localisation takes place with the simultaneous formation of the light emitting complexes, while at the second stage of further $D$ growth destruction of these. Specific example of such an influence of the $\gamma$-irradiation can be associated with transferring of hydrogen: breaking the weak $\mathrm{Si}-\mathrm{H}$ bonds, which are promoting the non-radiative transitions, and transition of hydrogen into structures of other oscillators. Some works $[6,7]$ have demonstrated broad possibilities for employment the UV radiation also for enhancing the photosensitivity and changing parameters of luminescent emission of various materials. Significant results have been achieved in this direction when using the radiation of excimer lasers.

Taking into account all the above said it seemed to be interesting to study the influence of $\mathrm{XeCl}^{*}$-laser irradiation of por-Si samples on their luminescent properties, in particular, on the shape of the $I_{\text {lum }}(T)$ curve.

\section{EXPERIMENTAL SETUP}

Por-Si samples obtained by applying the anodic selective etching to silicon plates oriented relatively to (100) crystallographic axis have been investigated. The etching had been carried out in an etchant consisting of $50 \%$ of ethanol and $50 \%$ of hydrofluoric acid. Details of the 
por-Si layers formation are described in [8]. That is why we only note here that the porosity of the samples, determined by the gravimetric method, constitutes $65 \%$ whereas the porous layers thickness equals about $25 \mu \mathrm{m}$. Such parameters of porosity and porous layers thickness were reached at the current density of about $30 \mu \mathrm{A} / \mathrm{cm}^{2}$ and of 20 minute process duration. Depending on etching conditions, all the samples investigated may be optionally broken into two groups differing by the location of the main light emission band. These groups are: i) group 1 having the emission band maximum at 610 $\mathrm{nm}$ and ii) group 2 having the maximum at $720 \mathrm{~nm}$. Photoluminescence (PL) spectra have been measured by means of the diffraction spectrometer of $\mathrm{C}-1$ type having a spectral slot width that not exceeds $0.1 \mathrm{~nm}$. PL excitation was performed with a $\mathrm{Hg}$ lamp of -500 type into $480 \mathrm{~nm}$ band that corresponds to maximum of excitation spectrum of the por-Si orange-red emission band. Variation and stabilization of temperature of the samples have been reached due to employment of UTREX cryostatic system. The temperature range was $4.2-300 \mathrm{~K}$ with $0.5^{\circ}$ step; in the low temperatures region, temperature was stabilized with accuracy of less than $0.5^{\circ}$. Irradiation of samples was performed by employing an $\mathrm{XeCl}^{*}$ excimer laser designed and made by the authors [9]. The laser possesses a wide-range functionality and is constructed according to the "master oscillator - power amplifier" optical scheme. Such a laser source design permits to reach the following parameters of radiation: $25 \mathrm{~ns}$ pulse width, $308 \mathrm{~nm}$ generation wavelength, $20 \mathrm{~m}$ J pulse energy, $5 \cdot 10^{-5}$ radians beam divergence, $\Delta \lambda=0.1 \mathrm{~cm}^{-1}$. When being irradiated, the samples were put into a special sealed chamber, which could be filled with various gases. The number of irradiation pulses could be varied (up to 150 pulses that correspond to the destruction threshold of the samples) in the $\mathrm{O}_{2}$-enriched atmosphere.

\section{RESULTS AND DISCUSSION}

Figs. 1 and 2 show fragments of the PL spectra of the orange-red region measured at various temperatures $\mathrm{T}$ (1-7) various doses of pulsed irradiation $(\mathrm{a}-\mathrm{c})$ for the samples of 1 and 2 types, respectively. Fig. 3 shows the temperature dependence of integral photoluminescence intensity of 1 st (a) and 2 nd (b) types of por-Si samples irradiated of various quantities of UV-pulses.

We focus on the following results:

- non-monotonic shape of $I_{\text {lum }}(T)$ dependence for the initial (unradiated) samples of type 2 and typical - monotonic - shape of such a dependence for the type 1 samples;

- change of shape of the Ilum(T) depending on the irradiation dose: from non-monotonic shape to monotonic one for the type 2 samples, Fig. $3 \mathrm{~b}$, as well as influence of the irradiation dose on magnitudes of coefficients $\left(d I_{\text {lum }} / d T\right)$ (Fig. 3a, $3 \mathrm{~b}$ ) for both types of the samples;
- pronounced deformation of the band's curve shape as a function of temperature as a result of faster decay of its short-wave wing (this effect inherent to the type 1 samples only and becomes more pronounced under higher irradiation doses, Fig. 1 (a to c)).
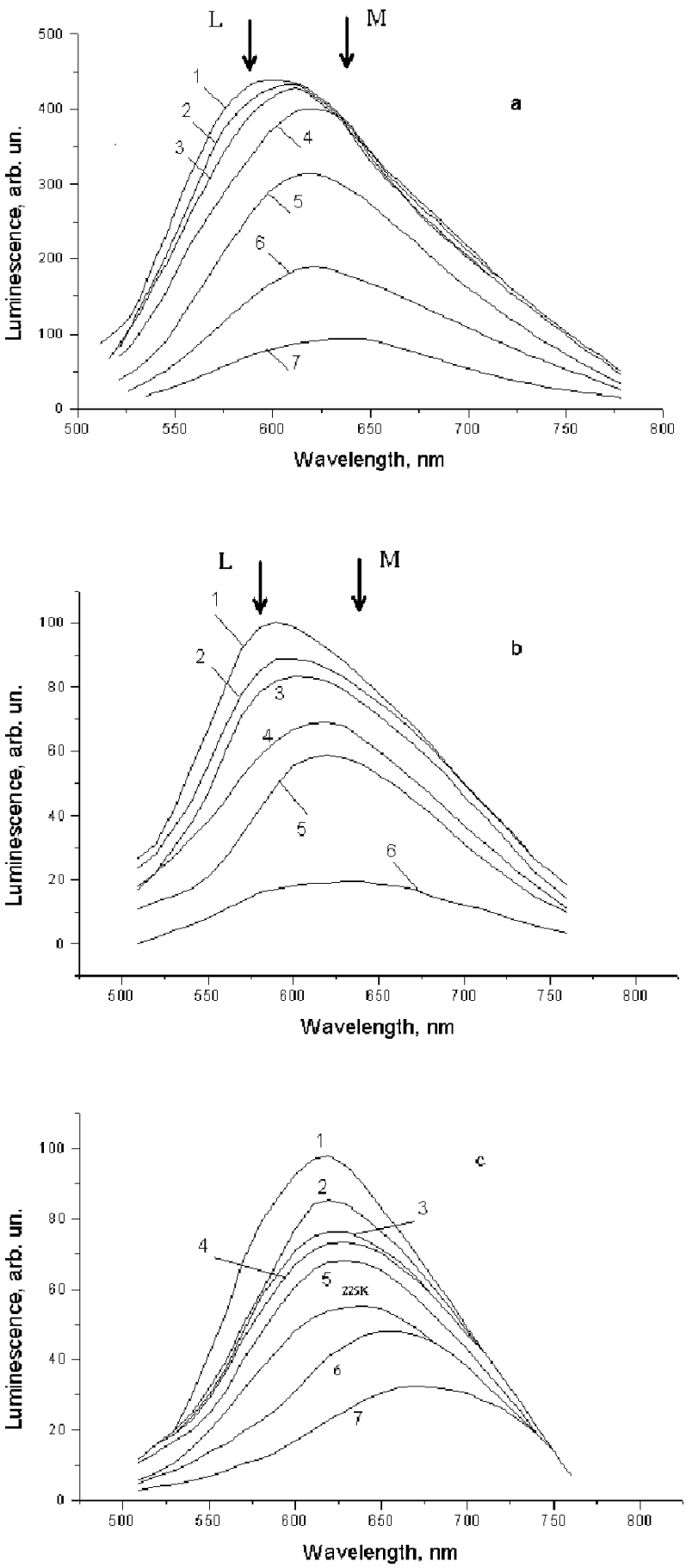

Fig. 1. Fragments of photoluminescence spectra of 1st type samples, obtained under various temperature values (1-7) and UV-radiation doze $(\mathrm{a}-\mathrm{c}): 1-5 \mathrm{~K}, 2-70 \mathrm{~K}, 3-$ $100 \mathrm{~K}, 4-150 \mathrm{~K}, 5-200 \mathrm{~K}, 6-250 \mathrm{~K}, 7-300 \mathrm{~K}$; а) non-irradiated sample, b) after 50 pulses of UV-radiation, c) after 150 pulses of UV-radiation. 
As a result, a spectral position of the maximum and the shape of the light emission curve for the type 1 samples at room temperature (Fig. 1c, spectrum 7) become identical to those for the type 2 samples spectra, (Fig. 2c, spectrum 7).
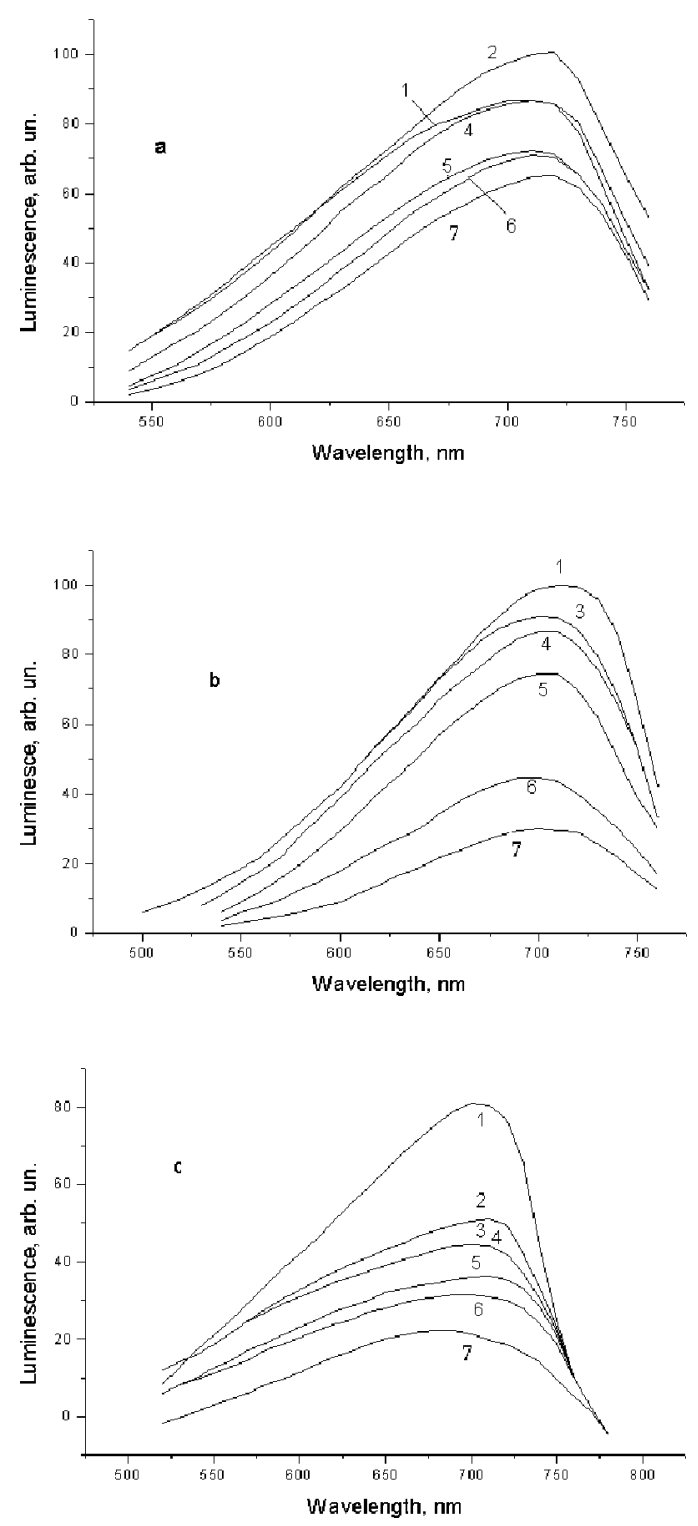

Fig. 2. Fragments of photoluminescence spectra of 2nd type samples, obtained under various temperature values (1, $2,4-7)$ and UV-radiation doze $(\mathrm{a}-\mathrm{c}): 1-5 \mathrm{~K}, 2-70 \mathrm{~K}, 3$ $-100 \mathrm{~K}, 4-150 \mathrm{~K}, 5-200 \mathrm{~K}, 6-250 \mathrm{~K}, 7-300 \mathrm{~K}$; a) non-irradiated sample, b) after 50 pulses of UV-radiation, c) after 150 pulses of UV-radiation.

Therefore, the experimental results, adduced in Figs. 1 to 3 , testify that by irradiating the por-Si samples with nsec-pulses of the $\mathrm{XeCl}^{*}$-excimer laser it is possible to influence on the fundamental $I_{\text {lum }}(T)$ dependence as well as to modify PL spectra of the type 1 samples to be similar to those of the type 2 samples ( 7 " spectra in Figs. 2 and 3 ). The cause of this is that for the type 1 samples, in contrast with the type 2 samples, one can clearly distinguish two components ( $\mathrm{L}$ and $\mathrm{M}$ bands) within the whole emission range; each of these differently reacts upon both the temperature variation and the irradiation dose. In particular, UV-irradiation dose increasing for the type 1 samples reduces the temperature decay time of the L band (see Fig. 2, a-c). Such a behaviour may be associated with two circumstances: (i) lowering of the energy barrier for transition of carriers participating in the recombination emission from "radiative" to "non-radiative" state; (ii) reduction of $\tau_{N R}$ time of the non-radiative transitions. It should be noted that when changing energy parameters of the centres responsible for emergence of the $\mathrm{L}$ emission band, one wait the position of its maximum also has to be shifted but really such a shift is not observed. This result forces us to put into basis of the model explaining the experimental results of Figs. 1 to 3, the fact of influence of UV irradiation on kinetic processes determining efficiency of the luminescent emission. Such an approach is consonant with that proposed by the authors of [1] model for explaining the nature of non-monotonic feature of the $I_{\text {lum }}(T)$ dependence which, as now can be realised, is inherent to $M$ component of the emission band. By analogy with [1] we
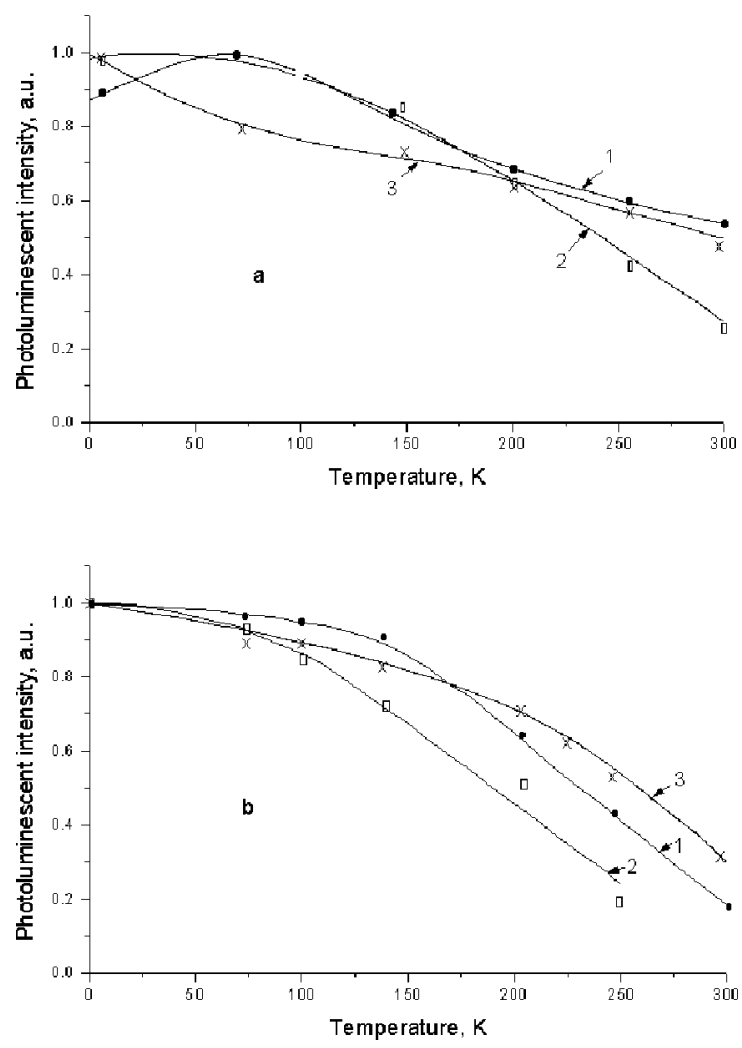

Fig. 3. Temperature dependence of integral photoluminescence intensity of 1st (a) and 2nd (b) types irradiated of various quantity of UV-pulses: 1 - before irradiation, 2 - after 50 pulses, 3 - after 150 pulses. 
can describe a nature of the non-monotonic feature of the $I_{\text {lum }}(T)$ dependence when basing on the net influence of temperature upon both the thermally activated transition of carriers from "non-radiative" to "radiative" states and the "bottleneck" effect manifestation in the non-radiative recombination of carriers [10]. As to the more concrete emission mechanism, it is difficult basing on the adduced results to give preference to any of the three following mechanisms which one founds in the literature most frequently: (i) mechanism connected with the quantum-size effect manifestation in the silicon fibres, (ii) mechanism stipulated by emission of the siloxen compounds located on surface of the silicon fibres, and (iii) combined two-component mechanism according to which the emission takes place as a result of the carriers recombination at the silicon quantum fibres or at the compounds that passivate a surface of such fibres. At the same time it is known that the por-Si surface is passivated due to formation of the $\mathrm{SiOH}, \mathrm{SiH}$, and $\mathrm{SiOx}$ compounds. Oxygen-containing Si compounds also promote the bright luminescence of por-Si. As to the hard radiation, it is accompanied, as a rule, first of all, by breaking the weak Si-H bounds [5]. New complexes that are formed with the participation of released hydrogen as well as interaction of silicon surface and atmosphere, can essentially influence the kinetics of recombination of the photoexcited charge carriers. It is the base from which one should explain the UV-activation of the temperature decay rate of the $\mathrm{L}$ band (Fig. 1). An in-depth description of the dependencies versus doze for the orange-red emission band decay of por-Si along the with results of investigations of IR reflection spectra will be given in a separate work.

This work was done with partial support of CRDF UP 1-368 grant.
[1] S. Finkbeiner, J. Weber, Thin Solid Films, 255, 254 (1995).

[2] T. Suemoto, K. Tanaka, A. Nakajima, Phys. Rev. B 49, 11005 (1994).

[3] N. F. Mott, Philos. Mag. 19, 835 (1969).

[4] Van Loo W, J. Lumin. 10, 221 (1975).

[5] V. Astrova, R. F. Vitman, Yu. V. Rud' at al., Fiz. Tekhn. Polupr. 30, 507 (1996).

[6] I. M. Chang, G. S. Chuo, D. C. Chang et al., J. Appl. Phys. 77, 5365 (1995).
[7] S. Migazaki, K. Shiba, K. Sakomoto, Optoelectron. Devices and Technol. 7, 95 (1992).

[8] I. V. Blonskyy, M. S. Brodyn, V. A. Tkhoryk et al., Semicond. Sci. Technol. 12, 11 (1997).

[9] S. M. Baschenko, I. V. Blonskyy, V. M. Puzikov et al., in Proceeding of SPIE International Conference on Optical Diagnosis of Materials and Devices for Opto-, Microand Quantum Electronics, v. 3359, 1997, p. 519.

[10] M. Ortuno, M. Pollak, Philos. Mag. B 47, 93 (1983).

\title{
ВПЛИВ ВИПРОМІНЮВАННЯ ХеСІ*-ЛАЗЕРА НА ТЕМПЕРАТУРНУ ЗАЛЕЖНІСТЬ ІНТЕНСИВНОСТИ ІНТЕГРАЛЬНОЇ ЛЮМІНЕСЦЕНЦІЇ ПОРИСТОГО КВАРЦУ
}

\author{
С. М. Башенко, І. В. Блонський, Ю. О. Скришевський \\ Інститут фізики Національной академї наук Украӥни, \\ просп. Науки, 46, Киӥв, Озоз9, Украӥна \\ E-mail:blon@marion.iop.kiev.ua, phone/fax:+38 (044) 265-31-38
}

\begin{abstract}
Уперше продемонстровано можливість впливати УФ-опроміненням на форму температурної залежности інтегральної інтенсивности люмінесценщії $I_{\text {lum }}(T)$ для зразків пористого кремнію. У зразках першого типу можна виділити дві спектральні компоненти, кожна з яких по-іншому реагує на опромінення та зміну температури. Зроблено висновок про те, шо різні форми залежности $I_{\operatorname{lum}}(T)$, які спостерігали різні групи дослідників на різних зразках пористого кремнію, зумовлені неоднаковим активним внеском у вислідну форму залежности $I_{\operatorname{lum}}(T)$ короткохвильової $(\mathrm{L})$ та довгохвильової (M) смуг люмінесценџї, а можливо, й інших смуг. Проаналізовано природу впливу УФ-опромінення на форму залежности $I_{1 u m}(T)$.
\end{abstract}

